\title{
Using Environmental Perception and Local Knowledge to improve the effectiveness of an Urban Park in Northeast Brazil
}

Valdecir da Silva Junior ${ }^{1 *}$ and Bráulio Almeida Santos

\begin{abstract}
The Xem-Xem Forest State Park (Parque Estadual da Mata do Xém-Xém) is a 182-ha Atlantic forest remnant located in the metropolitan region of João Pessoa, Paraíba, Northeast Brazil. Since its legal creation in 2000 , it has been facing several management problems and social conflicts that jointly has reduced its effectiveness. In this study we examined the environmental perception of residents surrounding the Park and the staff of the Paraíba state environmental agency (SUDEMA) in order to clearly identify those problems and conflicts and provide possible solutions. Semi structured interviews with both residents $(n=29)$ and staff members $(n=4)$ revealed that the Park is clearly valuable as a repository of biodiversity and a place for leisure and recreation, highlighting its great socioecological function. These benefits, however, were impaired or hindered mainly by fear of violence, lack of infrastructure, extremely limited staff and virtual absence of administrative structure. Furthermore, the protective measures of the Park were considered incipient and did not match the expectations and needs of local communities. We urgently recommend (1) the creation of the Park's management council, (2) the development of its management plan, (3) the implementation of public policies surrounding the area to ameliorate conditions for public use and improve biodiversity protection and (4) the continuity of ethnographic researches focusing on the relationship between local communities and the Park.
\end{abstract}

Keywords: Local perception, Ecological knowledge, Environmental policy, Protected area, Participative management.

${ }^{1}$ Programa de Pós-Graduação em Biologia Vegetal, Universidade Federal de Pernambuco, Recife, Brazil. Av. da Engenharia, s/n - Cidade Universitária - CEP: $50.740-600$

${ }^{2}$ Departamento de Sistemática e Ecologia; Universidade Federal da Paraíba, João Pessoa, Paraíba, Brazil, Castelo Branco CEP:58.051-900 


\section{INTRODUCTION}

Urban protected areas provide opportunity for teaching environmental processes and conservation to a large number of people, including those who lack the means or motivation to visit nonurban areas where wildlife is abundant (Dearborn and Kark 2010). In Brazil, protected area (PA) also known as conservation units (UC), have been created and implemented in urban landscapes to protect natural resources and its associated biodiversity, as well as to offer environmental services and improve citizen's quality of life. Federal Law 9.985/2000 establishes the National System of Conservation Units (SNUC in Portuguese) and legal basis for the creation, deployment and management of 12 categories of UCs with varying levels of protection (Brasil 2000). The state of Paraíba has eight protected areas in the category of Parks, a category in which direct use of natural resources is not allowed and public use for recreation, education and research is recommended. The Xem-Xem Forest State Park is a 182-ha Atlantic forest fragment embedded in the metropolitan region of João Pessoa, the easternmost point of the Americas. It is a typical urban PA in Brazil with numerous problems, which have prevented it to achieve its conservation goals. This low effectiveness makes the Xem-Xem forest a typical "paper Park", i.e. those legally created parks that actually do not comply with their socioecological goals due to the lack of political, financial, or administrative constraints (Bensusan 2006; Brito 2000; Dourojeanni 2002). Improving the effectiveness this and other Brazilian urban "paper Parks" is urgently needed not only to fit them to the SNUC, but also to help the country to achieve the Aichi biodiversity targets for 2011-2020 decade (www.cbd.int/sp/targets/).
Urban Parks are also strategically important to ensure citizen's quality of life in societies where urbanization increases rapidly (Chiesura 2004; Kaplan 1985; Ulrich 1984), helping to guide forms of environmental management and growth patterns of urban areas (Cardoso et al. 2015). Besides connecting patches of original ecosystems (Hunter and Hunter 2008; Matteson et al. 2013) and safeguarding biodiversity (Alvey 2006; Brun et al. 2007; Savard et al. 2000), urban parks provide recreational activities, tourism, environmental education and research as well as protection of cultural, historical and existential values for the surrounding population (Kinker 2002). However, it is recognized that only implementation of protected areas is not sufficient to ensure socio-environmental benefits. The management model predominantly used in the creation of Parks does not consider local participation in their designing, creation and implementation. Thus, it has been common the lack of public participation and interest in the decision-making process regarding the implementation of parks, affecting the principles of "good governance". "Good governance" is achieved through the intelligent and balanced articulation of all actors interested in the development of a territory, the so-called stakeholders (Sachs et al. 2010). Good governance has its origin in sociology and assumes a management based on social participation and decisionmaking groups and stakeholders (Donaldson and Preston 1995; Silveira et al. 2005). As defined by Sachs et al. (2010), it is a more democratic management system that seeks to match the interests of different groups, being aligned with the "participatory governance" and increasing the transparency of all processes involved. From the stakeholder theory perspective, 
management based on social participation should pay special attention to the most important social actors, those who works in the establishment of management actions, as well as those who act in the general politics and perform decision-making (Donaldson and Preston 1995).

In recent years conservation practice has shifted to involve indigenous people and local communities in PA management (Bawa et al. 2004; Brechin et al. 2002). We have witnessed the emergence of new models of management and conservation projects based on experiences that seek dialogue with the different social actors involved, considering the perceptions and expectations of the local population and their direct participation in PA planning and management (Bensusan 2006). The meaning of 'perception' has relation to the knowledge acquired through direct and immediate contact to objects in a sensorial space (Piaget 1969), to a process of organization and interpretation of received sensations from the environment (Davidoff 1993) or even a response by senses to external stimulus in which some phenomena could be clearly recorded or blocked (Tuan 1974). Environmental perception began to be discussed in the environmental researches in the mid-60s (Rodrigues et al. 2012) and since then has been considered in the analysis of man-environment relations to understand the differences in perceptions between two groups, such as local communities and national planners (Whyte 1977). Studies based on environmental perception suggest that not only the relationship between man and environment can be studied, but that prospects in scientific, political or social research can be elucidated with this approach (Pacheco and Silva 2006). According to Del Rio (1991) and Ferreira (2005), the term perception includes the bio-physiological perceptions and the images we mentally form about reality, our memories, experiences predilections, interpretations, attitudes and expectations. Thus, preliminary studies on the environmental perception in a given population may assist the process of developing programs defined according to the identity, values, interpretations and local relationships with the environment by different groups (Panquestor and Riguetti 2008).

Environmental perception has been used to guide the management of PAs (Sammarco 2005; Carneiro 2011; Kärre 2007; Rodriguez-Carreras et al. 2014; Trakolis 2001), define long-term strategies for animal conservation (Ceríaco 2012; Conforti and Azevedo 2003; Nyhus et al.1999), assess the knowledge of plant users (Cunningham 2001; Medeiros 2013) and the local environmental knowledge of traditional communities about fishing resources (Alves and Nishida 2002; Alves et al. 2005). People's perceptions might produce useful information that could be incorporated into the decision-making process and lead to the resolution of conflicts between local people and Park authorities by improving attitudes and altering behavior (Manfredo et al. 2004; Trakolis 2001). Local participation in PA management process can thus provide the basis for the development of conservation strategies in order to make them more effective. There has been growing international recognition that traditional and local ecological knowledge can be useful sources of information to complement "western scientific approaches" to resource management (Chelimsky 1991; Berkes et al 2000; Zabel et al. 2002; Hurrell and Albuquerque 2012). Thus, understanding how the surrounding population perceives an 
urban PA and its natural elements, such fauna, flora, and the local landscape, is also important to guide actions of both managers and community members, and to approach the PA to the objectives determined by law. In this sense, our goal in this study was to assess the environmental perception of residents surrounding the Xem-Xem Forest State Park and the staff of the Paraíba state (Brazil) environmental agency (SUDEMA) in order to clearly identify the main problems and conflicts affecting the Park and provide possible solutions.

\section{MATERIAL AND METHODS}

\section{Study site}

The Xem-Xem Forest State Park (7'07'29, 96"S and 34 $\left.55^{\prime} 55,41^{\prime \prime} \mathrm{O}\right)$ (Figure 1) is a 182-ha, Atlantic forest fragment located in the town of Bayeux, state of Paraíba, Northeast Brazil (Lourenço et al 2009). The Park is immersed in a heterogeneous landscape composed predominantly of urban settlements, including a few agricultural stands, highways and an international airport. The Park is

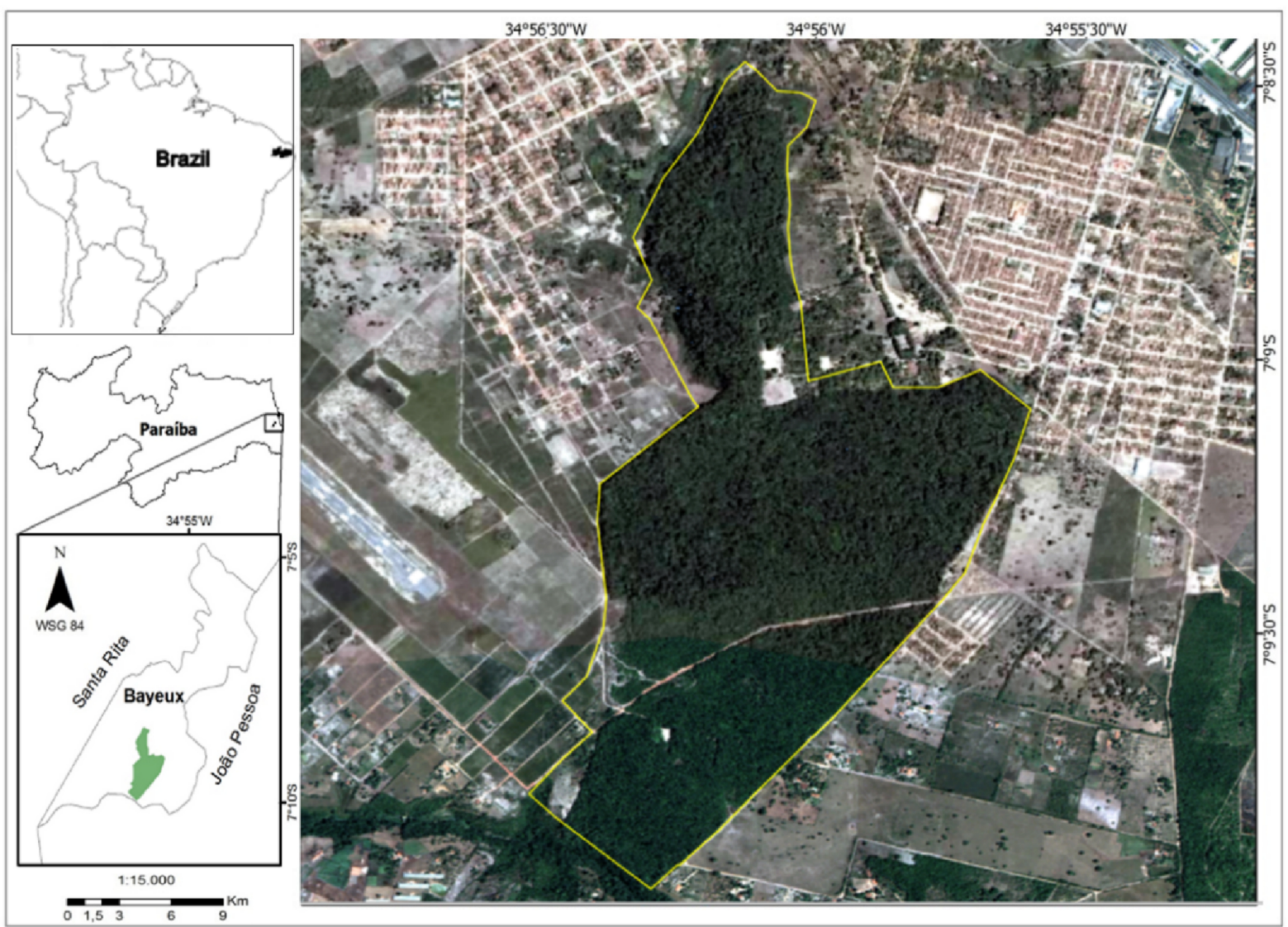

Figure 1. Location of the Xem-Xem Forest State Park in the city of Bayeux, Paraíba state, Northeast Brazil. The enlarged image shows the boundaries of the Park (yellow line) and the surrounding communities. 
home to an irreplaceable biodiversity (MMA 2007); it increases the thermal comfort locally and protects part of the historical and cultural heritage of the region. By safeguarding the headwaters of Meio's river and part of the Marés riverbanks, it also contributes significantly to the water supply of the most populous region of the state. Even if it has been decreed as protected area since 2000, the Park has not yet a management council and a management plan, both should have been created by 2005 following SNUC determination. The Park has its geographical boundaries totally unprotected, which in practice translates into disordering, unauthorized public uses.

\section{Data collection}

This study presents an exploratory research considering an ethnographic approach, not excluding quantitative methods (Neves 1996; Pope and Mays 1995). We made the recognition of the reality in the communities surrounding the Park through indirect observation and then select the main aspects to be considered in the construction of semi-structured questionnaires. According to Ferreira (2005), the indirect observation consists in the analysis of secondary sources and evidence observed by the researcher to show the effects of human action on the landscape as a measure of behavior. We applied two semi-structured interviews using a script with open questions for 29 local residents of the communities surrounding the Park and four SUDEMA staff members involved in its administration. In semi-structured interview technique, "the interviewer asks questions in a predetermined order, but within each question is relatively great the freedom of the interviewee to respond, or even other issues may be raised whenever something interesting and not foreseen in the original list of issues appear" (Abílio and Sato, 2012). Our script addressed socio-economic issues and questions about environmental perception and local knowledge about the Park for both groups, as follows: a) How would you describe the Park?; b) What is the purpose of the Park?; c) What are the problems you see in the Park?; d) How would you improve the conditions of the Park?; e) What are main use forms of the Park by communities members?, only to residents; and f) What are the priority measures of the environmental agency for the Park?, only to staff members. Additionally, we asked the residents for their perception about the local fauna and flora to examine their relationship with the natural elements of the Park.

The first participant was suggested by a political leadership which we made contact. This participant came from the "Matinha" community, and then he indicated more potential participants at the "Mariz" community. In both communities, we first introduced the research goals to the participants and informed them about the non-obligation of its participation. We carried out the interviews using the "Snow ball" method proposed by Goodman (1961) to select the respondents, in which "an individual is recruited and then indicates their relationship to other people to be also part of the sample". In this approach, the sampling is considered satisfactory when the answers are constant among most respondents. So, at the end of each interview, we were accompanied by each resident until the next participant indicated, giving continuity to the collection of speeches. Interviews with staff members occurred in a similar way. We contacted the SUDEMA and after getting authorization for the research and indication of a staff, we 
began the interviews. In total, we carried out five interviews with the SUDEMA staff, however, a participant declined and asked for being removed from the study. We conducted the fieldwork and interviews from July to September 2013. Speeches of respondents were saved on a recorder for later transcription and data analysis. We adopted three approaches as recommended by Whyte (1977) in his seminal work: observing, questioning and listening.

\section{Data analyses}

We used the content analysis method proposed by Bardin (1977), a technique of communication analyses that seeks to classify the speeches, spoken or written, in themes or categories that are able to assist in their understanding and meanings. Data analyses followed three main steps, namely: 1) pre-analysis - general reading, organization and definition of themes or categories of analysis; 2) exploration of the material-selection and grouping of units (sentences, paragraphs, words) in new subjects or intermediaries categories; and 3) treatment of the results, inference and interpretation of the lines through themes or final categories. Because the responses of participants may be classified into one or more categories, the percentage of responses shown in the Results section often did not match the number of respondents of each category. To compare the environmental perception of residents and staff members, we selected four questions common to both groups involving aspects of Park description, function, problems and solutions. For each question, we calculated the Bray-Curtis similarity index, which varies from 0 (totally different perception) to 100 (identical perception). As recommended by Clarke and Gorley (2001), the numbers of citation were sqrttransformed and standardized to avoid any bias resulting from highly cited categories and differences in citation numbers.

\section{RESULTS}

\section{Profile of respondents}

About $54 \%$ of the respondents were male, $30.3 \%$ were 40 to 49 years old and $45.5 \%$ had uncompleted elementary education. In communities, $45.5 \%$ the respondents declared receiving a minimum wage ( $<300$ USD) as the only family monthly income. Among all respondents, $36.4 \%$ were born in the town of Bayeux, followed by $30.3 \%$ born in the capital João Pessoa. Only one respondent reported having been born in the site. In the communities, $44.8 \%$ have been living between one to 10 years around the Park, $18.2 \%$ of the women reported being housekeeper and $12,1 \%$ of the men mentioned joiner as their most common occupation. Other occupations included farmer, merchants, painters, masons helper, blacksmith, nurse, cook, contractor reformer. Three respondents declared themselves as retired and two students. Regarding the SUDEMA staff, $50 \%$ of respondents reported that they are in the role for 3 years, $25 \%$ are less than 1 year and $25 \%$ for over 19 years.

\section{Values, perceptions and knowledge about the Park by residents}

Most residents surrounding the Park reported to like where they live in. Among the reasons, they highlighted the nature, represented by the forest with its animals or environmental services, and the local tranquility. More cited animals were sloth, marmosets and fox, besides many bird species (Table 1). Knowledge of local flora 
by residents was also relevant, but apparently smaller than that of animals. The most representative family was Fabaceae, with four known examples, followed by Anacardiaceae and Bignoniaceae. The most commonly cited examples were cajueiro roxo, pau-brasil, ipês, pau d'arco, babatenon, embaúba and aroeira (Table 2). The feeling identified on the resident speeches was to belong to the place where they live in, reinforced by direct or indirect contact with natural landscape aspects perceived in the communities and the social links already established during the period in which the interviewees reside in the locality. However, it was possible to identify an ambiguous sense of affinity and aversion attributed to the forest, as shown in the following comments of interviewees:

"I always liked here, mainly due to the proximity of the forest. I think temperature is milder near the forest, is not so cold because the forest keeps the wind, right? "(respondent 8)

"I like this place. Special reason is the nature, to me is a good place. In the environment, we see birds, animals living freely. "(respondent 17)

"[...] I love living here. It was here that I built my family. It was here from the community that important friends of mine have left to the capital. Before, we had bathed in the Xem-Xem river. You could go with your own family, with your own father, with your own mother, it was a marvel, but nowadays the forest is abandoned. There is violence. It is dangerous to go there." (respondent 21)

Asking about the forest, $60 \%$ of the residents did not recognize it as a protected area, defining it as an abandoned or unprotected place. In addition, 58\% were unable to inform the role or importance of the Park. There is an informative board in front of the community, however, it is in bad condition and partially covered by the vegetation (Figure 2A). The Park was described as a dangerous place but still used as path to get the neighborhoods and a place for leisure or subsistence. Among those residents that declared not using the park at all, most cited the lack of security as the main reason. There are recurrent cases of violence in the community, including homicides within the Park, as pointed out in the following comments of interviewees:

"I do not use it because we are afraid. We do not have a surveillance, do not have a ranger. Here I don't have seen, ever. We just crossed the Park by car and yet still afraid." (respondent 7)

"[...] The bad thing about the forest is that it hides very thugs there, who use the forest to do things... as disposal of human corpses." (respondent 17)

Another remarkable problem perceived in the Park and communities was the lack of appropriate garbage deposit, cited by $40 \%$. During the interviews, residents also cited the occurrence of fires and the lack of sanitation as problems affecting the Park. During the fieldwork, deforestation, irregular sites for resting, and fires caused by illegal burning of trash were observed as well (Figure $2 \mathrm{~B}, \mathrm{C}, \mathrm{D})$. Due to the infrequent collection of the garbage produced in the communities, residents have no alternative than carried their garbage to the unprotected Park boundaries and burn it. The most noticeable negative change indicated by the residents was the considerable increase of garbage over the years. According to them, this problem is associated with the increasing population and consequently higher number of homes built in the communities. Deforestation has gradually increased as well, and some social actors linked it to the population growth in the 
locality. Few social actors did not notice problems in the Park, which can be explained by their distancing from the Park reality, or fear from exposing their speeches about issues such as violence, trafficking, drug use, garbage or logging for domestic uses, as shown in the following comments of interviewees:

"The problem we have is the lack of security, not even for the animals, which are already few. The pollution here is also common. People turns out remains of animals such as chicken waste, and turns on the edge of the forest. Does not have a
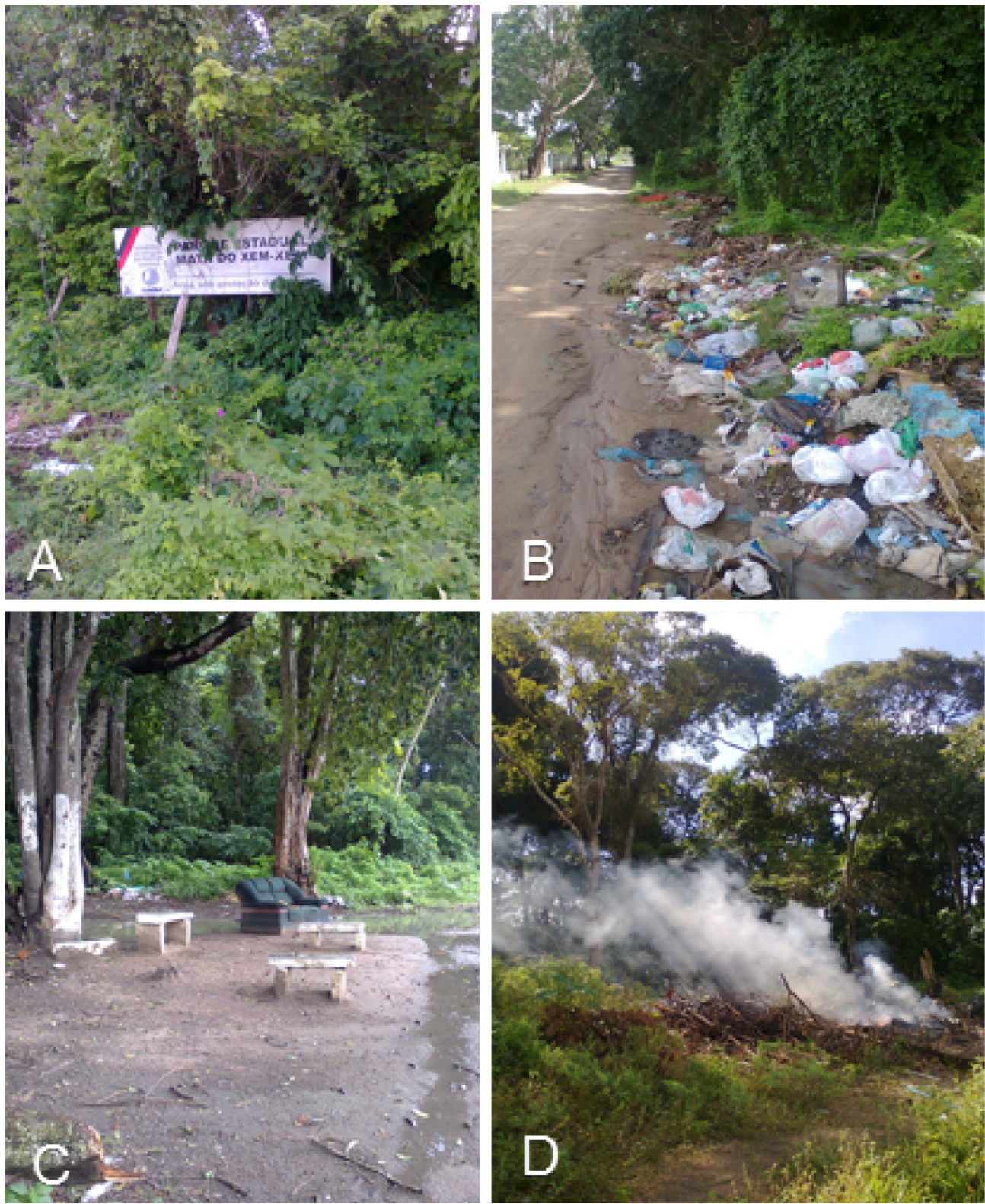

Figure 2. Problems identified at the Xem-Xem Forest State Park, Northeast Brazil: A - Indicative board of the Park in bad condition; B - Accumulated garbage at the edge of the Park; C - Limits of the Park used for landfill and construction of inappropriate places; D - Fire on the edge of the Park. 
Table 1. Species list of local fauna mentioned by residents surrounding the Xem-Xem Forest State Park, Northeast Brazil.

\begin{tabular}{|c|c|c|}
\hline Common name & Potential taxa identified & $\begin{array}{c}\mathrm{N}^{\circ} \text { of } \\
\text { citations }\end{array}$ \\
\hline & Mammalia & \\
\hline & Carnivora & \\
\hline Raposa (crab-eating fox) & Cerdocyon sp. & 8 \\
\hline \multirow[t]{2}{*}{ Gato do mato (little spoted cat) } & Leopardus sp. & 2 \\
\hline & Xenarthra & \\
\hline Preguiça (sloth) & Bradypus sp. & 15 \\
\hline Tatu (armadillo) & Euphractus sp. & 6 \\
\hline \multirow[t]{2}{*}{ Tamanduá (anteater) } & Tamandua sp. & 2 \\
\hline & Rodenthia & \\
\hline Coelho (wild rabbit) & Sylvilagus sp. & 1 \\
\hline \multirow[t]{2}{*}{ Cutia } & Dasyprocta sp. & 5 \\
\hline & Primates & \\
\hline \multirow[t]{3}{*}{ Sagui (marmoset) } & Callithrix sp. & 10 \\
\hline & Reptilia & \\
\hline & Squamata & \\
\hline Teiú (lizard) & Tupinambis sp. & 10 \\
\hline Cobra cipó (green snake) & Chironius sp. & 3 \\
\hline Cobra coral (coral snake) & Micrurus sp. & 2 \\
\hline Cobra d'água & Helicops sp. & 2 \\
\hline Cobra de veado & Corallus sp. & 1 \\
\hline Corre campo (mock viper) & Philodryas sp. & 1 \\
\hline Pico de jaca (bushmaster) & Lachesis sp. & 1 \\
\hline Jibóia (red-tailed boa) & Boa sp. & 1 \\
\hline \multirow[t]{3}{*}{ Sucuri (common anaconda) } & Eunectes sp. & 1 \\
\hline & Arachnidae & \\
\hline & Araneae & \\
\hline \multirow[t]{3}{*}{ Aranha caranguejeira (tarântula) } & Lasiodora sp. & 3 \\
\hline & Insecta & \\
\hline & Hymenoptera & \\
\hline Saúva (sauva ant) & Atta sp. & 1 \\
\hline
\end{tabular}




\begin{tabular}{|c|c|c|}
\hline Common name & Potential taxa identified & $\begin{array}{c}\mathrm{N}^{\circ} \text { of } \\
\text { citations }\end{array}$ \\
\hline & Birds & \\
\hline & Passeriformes & \\
\hline Canário belga (belgian canary) & Serinus sp. & 3 \\
\hline Canário da terra & Sicalis sp. & 2 \\
\hline Galo de campina (red-cowled cardinal) & Paroaria sp. & 3 \\
\hline Papa capim (Slate-colored seedeater) & Sporophila sp. & 2 \\
\hline Caboclo lindo & Sporophila sp. & 1 \\
\hline Lavandeira (masked water-tyrant) & Fluvicola sp. & 1 \\
\hline Pardal (sparrow) & Passer sp. & 1 \\
\hline \multirow[t]{2}{*}{ Sibito } & Coereba sp. & 1 \\
\hline & Psitaciformes & \\
\hline \multirow[t]{2}{*}{ Maracanã (four red-shouldered macaw) } & Diopsittaca sp. & 5 \\
\hline & Galliformes & \\
\hline Pavão (peacock) & Pavo sp. & 1 \\
\hline Guiné (guinea fowl bird) & Numida sp. & 1 \\
\hline \multirow[t]{2}{*}{ Jacú } & Penelope sp. & 1 \\
\hline & Falconiformes & \\
\hline \multirow[t]{2}{*}{ Gavião (roadside hawk) } & Rupornis sp. & 1 \\
\hline & Piciformes & \\
\hline \multirow[t]{2}{*}{ Pica pau (woodpecker) } & Picumnus sp. & 2 \\
\hline & Strigiformes & \\
\hline \multirow[t]{2}{*}{ Coruja buraqueira (burrowing owl) } & Athene sp. & 1 \\
\hline & Cathartiformes & \\
\hline Urubu (vulture) & Coragyps sp. & 1 \\
\hline
\end{tabular}

fence, you know, there is no vehicle to supervise." (respondent 6)

"Things are worse here. The amount of people is high now and the population increasing, consequently, increased garbage, increased deforestation; all of these things are causing more dirt." (respondent 20)

When we asked the residents for proposing improvement actions to the Park, $86 \%$ recommend improvements in physical infrastructure, which include the construction of a fence and increasing supervision and policing around. According to respondents, implementation of rigorous monitoring and surveillance in the area, especially around the Park, would help to make the Park safer, providing tranquility for those who use it as a 
Table 2 - Species list of local flora mentioned by residents surrounding the Xem-Xem Forest State Park, Northeast Brazil.

\begin{tabular}{|c|c|c|}
\hline Common name & Potential taxa identified & $\mathrm{N}^{\circ}$ of citations \\
\hline & Anacardiaceae & \\
\hline Cajueiro roxo (cashew foot) & Anacardium sp. & 5 \\
\hline \multirow[t]{2}{*}{ Aroeira } & Schinus sp. & 2 \\
\hline & Bignonicaeae & \\
\hline \multirow[t]{2}{*}{ Ipê roxo; Ipê amarelo } & Handroanthus sp. & 7 \\
\hline & Fabaceae & \\
\hline Pau Brasil (redwood) & Caesalpinia sp. & 1 \\
\hline Babatenon & Stryphnodendron sp. & 3 \\
\hline \multirow[t]{2}{*}{ Jacarandá (rosewood) } & Jacaranda sp. & 1 \\
\hline & Sapotaceae & \\
\hline \multirow[t]{2}{*}{ Maçaranduba (bulletwood tree) } & Manilkara sp. & 2 \\
\hline & Urticaceae & \\
\hline \multirow[t]{2}{*}{ Embaúba (trumpet tree) } & Cecropia sp. & 3 \\
\hline & Lamiaceae & \\
\hline \multirow[t]{2}{*}{ Urtiga branca (write nettle) } & Lamium sp. & 1 \\
\hline & Lecythidaceae & \\
\hline \multirow[t]{2}{*}{ Imbiriba } & Eschweilera sp. & 1 \\
\hline & Malpighaceae & \\
\hline \multirow[t]{2}{*}{ Murici (murici tree) } & Byrsonima sp. & 1 \\
\hline & Moraceae & \\
\hline \multirow[t]{2}{*}{ Pé de jaca (jackfruit) } & Artocarpus sp. & 1 \\
\hline & Myristicaceae & \\
\hline \multirow[t]{2}{*}{ Urucuba } & Virola sp. & 1 \\
\hline & Poaceae & \\
\hline Bambu (bamboo) & Bambusa sp. & 1 \\
\hline
\end{tabular}

path to the other neighboring communities, as pointed in the following comments of interviewees:

"It would build a wall around it, to avoid unwanted intruders." (respondent 8)

"Those garbage and the lack of more supervision" (respondent 19)
During the interviews, security was the main issue addressed by social actors when referring to the benefits generated by improvements to the Park, indicating that the problem of violence is related to the current status of the area. They also expected that improvements in the park could decrease 
waste amount, offering a recreation area conducive for residents, improving communities' infrastructure and generating opportunities linked to touristic activities, as shown in the following comments of interviewees:

"Sure, for all of us here, could be an area more secure, more health [...] The population needs it (the forest), right?" (respondent 27)

"Certainly would be improved, even in the issue of pollution, trash that people put there." (respondent 19)

"Yes, it will bring tourists to look at the forest, for sure. People who live in another city will be able to come and visit." (respondent 5)

Perception and knowledge about the Park by the SUDEMA staff

During the interviews, some staff reported that they never had a close contact with the Park before or visited it only a few times. However, they demonstrated that the Park does not comply with the standards laid down by SNUC and has not been effective in conserving local biodiversity or even promoting social benefits effectively, as shown in the following comment of interviewee:

"In my view it is not a UC because it has no management council. The SNUC says that UC should have a participatory council and this hasn't happened since its decree." (staff 3)

For $55.6 \%$, the Park is an ecological and social relevant area to surrounding communities, revealing their role to maintain ecosystem services as well as the local historical and symbolic values. Moreover, $22.2 \%$ also described it as an area of territorial conflicts. Part of the conflict is due to the current coverage area, which has been not completely regularized yet.
According with the SNUC law, land domain must be public for the Park category, with no private property. We observed the existence of squatters inside the Park, which is also prohibited. Similar to residents, the lack of local infrastructure was noticed as the main problem by $44 \%$ of the staff members, followed by illegal occupations (22\%). During the direct observations, we detected the existence of the irregular houses around and within the Park, as reported in interviews with local residents. We considered approaching these illegal residents, but respondents did not recommended it for security reasons, as shown in the comment below:

"The squatters simply took possession of the Park. About the illegal occupation, we have to find a way to remove them. There is a proposal from the Security Department to build a chain on the edge of UC, and that's another problem we need to solve. We do not know how to deal with this issue yet." (staff 1)

When asked about the role of the Park, $60 \%$ of the members reported that its main function is to preserve the remaining forest. It was noticed that beyond the technical knowledge about the importance of the Park to the conservation of local biodiversity, one of the respondents stressed the importance of local participation of the surrounding residents in Park management. Other speeches emphasized the ecosystemic value of the Park, giving its protection of local natural resources and the quality of life for surrounding communities, as shown in the following comments of interviewee:

"Its role is maintaining the fragment, however I think the community should participate in this action through environmental education, right? Environmental education and conservation, I think both should work together." (staff 1) 
"[...] The Park mitigates the impact of the airport and protect a river that exists there. Usually the forest serves filtering that river." (staff 2)

"It serves to ensure the quality of life. It is an extensive forest [...] the Park has features that reflect the quality of life." (staff 3 )

For $40 \%$ of the respondents the main measure taken by the managing agency is the land regularization, from which would be possible the regularization and removing squatters. The current management strategies reported were the planning of environmental education activities to raise awareness of the surrounding communities and fence construction around the Park. The latter has been seen as one of the most common and urgent claim made by residents. However, as noticed by staff members, management changes, the bureaucracy in terms of public policies and insufficiency in the staff members are the
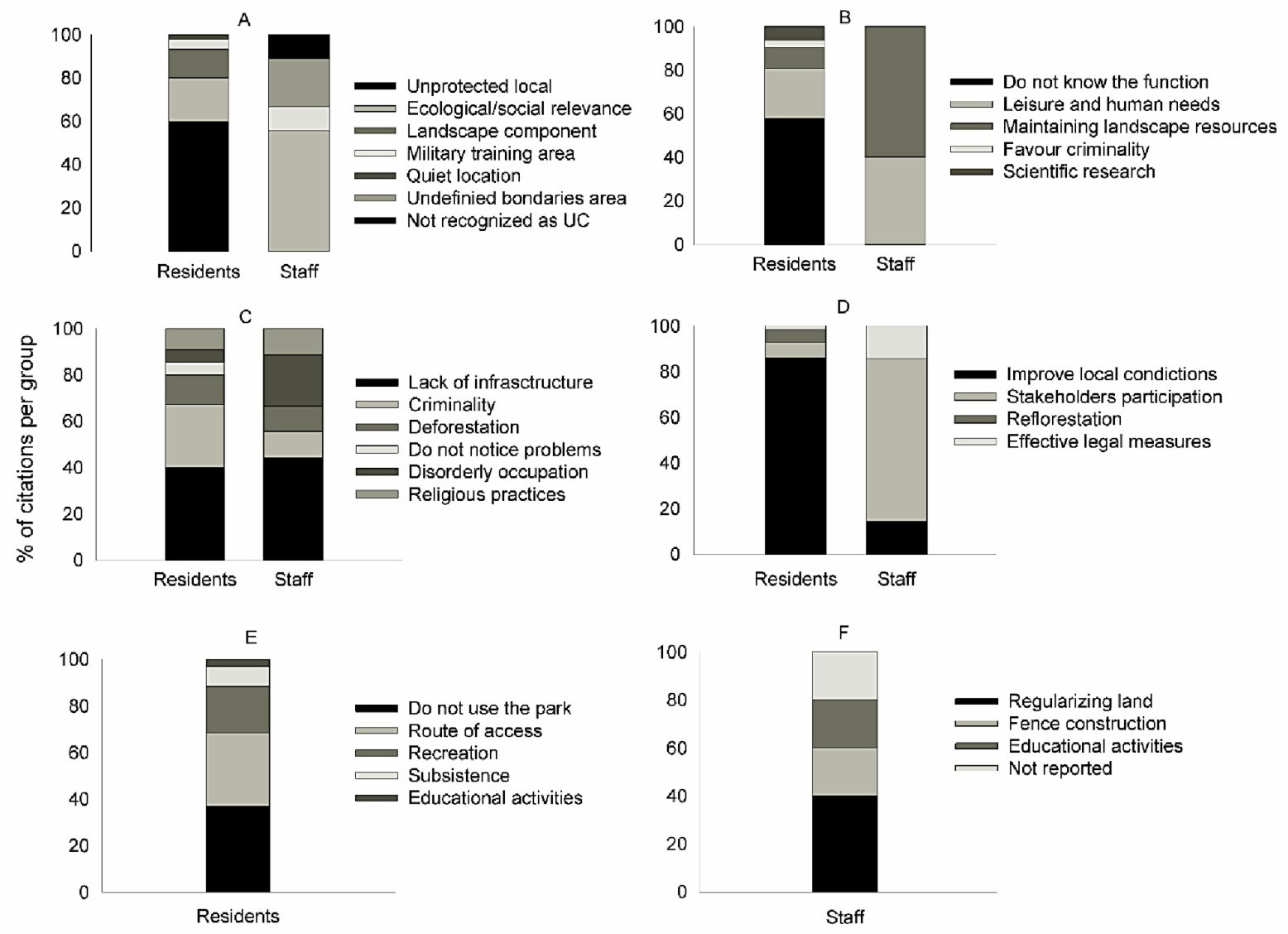

Figure 3. Main themes cited by residents and staff about knowledge of the Park: A - Description of Park; B - Role of the Park; C - Problems seen at the Park; D - Suggested measures to improve the Park; E - Main use of the Park by residents; F - Priority measures for Park by staff. 
main difficulties faced by the environmental agency to implement those local measures. Comments concerning difficulty faced by environmental agency are shown below:

"Now we need to regulate the area of the forest to remove the irregular housing [...]." (staff 1)

"The first priority is to create participatory management through a management board made up of civil society, public agencies, private agencies [...] more or less made up of 30 elements. The priority is the participation." (staff 3)

"The priority currently is encouraging (residents) to do reforestation [...]" (staff 4)

The most suggested measure to improve the Park conditions was to encourage the stakeholder participation $(71.4 \%)$ through the creation of a management council and conducting awareness campaigns with the nearby communities. Measures suggested by the SUDEMA staff are in accordance with the participatory management model still discussed and encouraged for the settlement of disputes and maintenance of protected natural areas. The speech of respondents showed that the inclusion of participation of social actors and other stakeholders can be prioritized in an attempt to make more effective conservation measures for the benefit of the quality of life of those involved. The approach of the parties could still be made through a continuous and effective debate on the benefits offered by the Park as well as through the awareness of those involved on the impacts caused by currently local development activities. It is important to note that the SUDEMA already includes in its current measures environmental education activities aimed at schools in the surroundings of the Park. Comments below emphasized the continuity of these activities and the need to go beyond school boundaries and expand the actions to all community members.

"[...] It would be also important an awareness campaign about the Park and its importance to people around it, about do not deforest, do not littering." (staff 2)

"[...] Alone we will not succeed in any action. Not only government agencies, but community schools, all together. It's not just work only public manager. Each of understanding and doing their function. For me this is the main strategy." (staff 3 )

"There should be a management policy, the stage of the zoning and management plan should be performed. There are other actions that should be done, but the important thing is to have the head office and the management board, so the rest will come gradually." (staff 1)

As seen on following quotes, the staff members expected the local improvements could bring residents to forest mainly by intensifying the feeling of belongingness and the quality of life provided by green area adjacent. They also encourage that the communities feel the Park belongs to them, safeguards their cultural values and accordingly residents should feel responsible for Park maintenance and protection.

"[...] The Park has a great relevance there, the ecological and social level, because there's some communities there that has a cultural bias that has to be taken to the other generations. There are elsewhere in the world, as well as in Brazil, examples of areas that reflect the improvement of air quality, quality of life right, but the immediate benefit is you have pride of place, is that you feel that area, who lives there will protect how to protect something they appreciate." (staff 3)

"[...] Consider the Park as their heritage, for they feel empowered, so they can say: this is mine, this is our, from our community." 
(staff 4)

Similarity in the environmental perception of residents and SUDEMA staff.

According to Bray-Curtis similarity index, both residents and staff members perceived the same problems in the Park $(82.4 \%$ of similarity) and share half $(49.2 \%)$ of the potential solutions for those problems. However, they differed considerably in the way they describe the Park $(33.8 \%$ of similarity) and recognize its functions $(39.7 \%)$. These differences in environmental perceptions clearly indicate the need of a more participatory model of management.

\section{DISCUSSION}

\section{Local knowledge and the relation of residents with the Park}

The physical environment perceived by residents plays an important role in the distinction of the values and local representations of the Park. It is important to take into account that the landscape is not built only by physical or cultural aspects, but also for the experience and expertise with the world-lived, from which people attribute meanings, values, symbols and myths (Relph 1979). The local values based on family relationships and the symbolic elements from nature help to identify a topophilic relationship between the residents and the community where they live in. The topophilia can be defined in a broad sense as all affective ties of humans with the environment material, which differ profoundly in intensity, subtlety and expression (Tuan 1974). In this sense, human response to the environment can be basically aesthetics, related to the visual aspects, but may be also a tactile response when it sets out from the contact with the elements from the environment, such as air, water or earth, and may be still constructed from feelings related to the place. Its inverse, topophobia, represents the aversion or contempt related to perceived object or sense. Although the elements from nature and ecosystem services are symbolic representation of communities, perception of crime and violence inhibits residents to approach the Park, reinforcing the feeling of insecurity, fear and the notion that the Park is a separate element of the landscape. Clearly, residents present a mix of topophilic and topophobic feelings regarding the Park.

The non-recognition of the Xem-Xem forest as a PA by residents can be considered a result of the exclusion of the surrounding communities from the process of its creation since 2000 , as well the limited presence of SUDEMA at the locality. The consequences of this non-recognition is a virtually inexistent participation of local actors in Park protection, increasing the distance between residents and the PA, which, in turn, decrease the feeling of belongingness. It was evident that the forest tracts protected by the Park has its value as a repository of biodiversity, place for leisure and recreation, among other environmental services. However, such indirect uses are hampered or prevented by fear of violence and inhospitable current conditions of the Park, as indicated by the large amount of waste observed along the tracks and forest edges. This ambiguous relation presented by the residents can be also perceived as a reflection of a historical perception of the forests by different cultures over time, since the primitive people treated the forests with fear and veneration (Leão 2000).

Researches developed in urban parks have shown that densely forested areas have consistently been associated with fear (Kuo and Sullivan 2001). These authors also 
pointed out that dense vegetation provides potential cover for criminal activities, possibly increasing the likelihood of crime and certainly increasing the fear of violence. The perception and the indirect contact to a dense green area around communities can inhibit the sense of security linked to a clear observation of the landscape, as fear is higher where vegetation blocks views (Fisher and Nasar 1992; Kuo et al. 1998; Michael and Hull, 1994). The speech of respondents corroborates this notion and also corresponds to what was reported by Sá (2000), who argued that there is a feeling of insecurity associated mainly with urbanization. The same problem is described by Groff and McCord (2012), who argue that offenders may be attracted by urban parks because these places are usually, uncontrolled public areas with poor lighting.

For residents, the implementation of more rigorous monitoring and surveillance in the area would contribute to make it a safer place, providing tranquility enough to move to other communities. It is evident, therefore, the importance of engage polices and rangers to act at the Park and nearby communities. The public security policy, as the policy of nature protection, is also marked in the exercise of participatory democracy, through the advice of institutions (Peixoto et al 2010). Experience has shown that the inspection will be more effective only if accompanied by an improvement in socioeconomic conditions for the population, which should improve education and bring a positive cultural change (Philippi Jr et al. 2004). It also demonstrates that an effective change in the Park will only be achieved if accompanied by improvements in local infrastructure of communities, such as garbage collection, street paving, and basic sanitation. The importance of public PAs with adequate physical structure (benches, playground, etc.), well cared plants, good lighting and good visibility in poor communities has been long emphasized (Talbot and Kaplan 1984). In the case of the Xem-Xem Park, the construction of a protective fence is critical to improve its infrastructure. Both decorative and security fencing may serve as a territorial marker clearly delineating sidewalk space and activity from Park space (Jeffery 1971; Newman 1972; Taylor and Harrell 1996). Residents recognized it and report that these measures would help to prevent problems such as inadequate garbage disposal, selective logging, entry of malicious persons and illegal buildings along Park boundaries.

Despite the use of the Park and its natural elements, some people use animals such as snakes and armadillos as food. This habit is still quite common especially in communities near the urban forest fragments in the region. Reptiles have served as an important source of protein for human populations around the world (Alves 2012), although mammals comprise the preferred source of food because of their size and the possibility of yielding a greater return for the energy invested in hunting (Albuquerque et al. 2012). Knowledge about the large amount of birds observed at the Park can be associated with a culture of rising these animals for domestic and economic purposes. Culturally, the group of birds is one of the most coveted by the people, and is also one of the most illegally sold in fairs of Northeast Brazil (Rocha et al 2006). The knowledge of the flora by residents is associated with medicinal use of some plant parts or linked to ornamental and landscape local values. Altogether, these direct uses of plant and animal species should be eliminated from the Xem-Xem Forest State Park, as they are not permitted in protected 
areas belonging to the category of park.

\section{The challenge faced by the SUDEMA}

As noticed, the speech of staff members is predominantly based on legal knowledge about creation and maintenance of PAs, including the socioenvironmental benefits generated by the presence of a PA and the recognition of the distinct stakeholders participation in PA management. Unlike residents, who recognize the animals and plants as valuable natural elements for the forest and communities, staff members involved in solving problems of the Park emphasize the link between ecosystem processes and quality of life, as well as the historical and cultural value that the Park has to surrounding residents, especially to older local generations. Such speech demonstrates the importance of considering the social and cultural aspects of the surrounding populations in PA management, rescuing their local knowledge. As recognized by SUDEMA members interviewed, the Park was declared PA without considering public participation in its creation, which is a recurrent problem in the huge, but poorly effective Brazilian system of PAs (McLaughlin 2011).

Another problem faced by Brazilian PAs that is also present in Xem-Xem Park are the conflicts in land uses. Alves et al. (2010) identifies non-regularization as a potential factor of conflict in conservation initiatives, preventing investment, complicating the planning, and reducing effectiveness. Brazilian law (SNUC) provides that occupiers established prior to the creation act should be expropriated, financially compensated and the land acquired by the state. Based on our findings, the first step to be adopted for the solution of current conflicts in the area is the creation of a management council, as expected by the SNUC. The management council is responsible to determine specific regulations associated with the zoning system and the management actions for specific natural resources (Redford and Fearn 2007). Since the 1980s, a discourse on decentralization and local participation emerged among large international conservation organizations, helping to shift away from previous exclusionary approaches for biodiversity conservation (Campbell 2002). However, planned or claimed devolution and decentralization of PA control to local communities do not occur in reality (Benjaminsen and Svarstad 2010; Blaikie 2006; Nelson and Agrawal 2008), and in the case of Brazilian PAs in the category of park, the council is advisory only, with a few seats with no decision-making power reserved for community organizations and other interested institutions. All decisions are therefore SUDEMA's responsibility.

The advisory council, however, must consider the knowledge (traditional or not) and the participation of surrounding communities in its decisions. Comanagement is one of the promising arrangements to address potential conflicts between multiple objectives such as biodiversity conservation, local economic needs, indigenous rights, and equitable sharing of benefits (Alves et al. 2010; Borrini et al. 2004). Examples in which popular participation and local knowledge resulted in a satisfactory process in the management of PAs can be seen in Marimauá Sustainable Development Reserve in the state of Amazonas, Brazil (see McLaughlin 2011) and Makuira National Park, in Guajira peninsula, northeast of Colombia (see Premauer and Berkes 2015). Inclusion of traditional ecological knowledge, 
participatory governance strategies, the continuation of traditional livelihoods, and updating and enhancing the efficacy of traditional resource management strategies (McLaughlin 2011) are among the reasons for successful management of theses PAs. Although co-management is not permitted by law for the Xem-Xem Park, the establishment of the advisory council is urgent and should listen to the local communities. The high dissimilarity observed in the perception of staff members and local residents in terms of Park description, functions, and potential solution for its problems also justify the proximity between these actors.

A second step urgently needed is the creation and implementation of the Park management plan, which should have been done until 2005 and implemented since then. According to the SNUC, the councils of any PA have five years after the publication of its legal creation to produce the management plan. The latest trend is that such planning is participatory, involving society as a whole, in particular the neighboring communities and environmental Non-Governmental Organizations (NGOs). It is recommended a comprehensive survey of flora and fauna and other diagnostics of the physical and social environment (Philippi Jr et al. 2004). The survey, along with the Park zoning, will help SUDEMA staff to define public use strategies expected for the category of park, such as environmental protection, education, research, ecotourism, and leisure. Lots of schools and universities could extend their activities to the Park. More than a million people live in a $20 \mathrm{~km}$ radius and could visit the Park if a solid program of public use is part of the management plan. Tourists could also have access to the area and the nearby airport might divulgate the need to protect the Park.
Nonetheless, these actions will not be effective without a profound change in the way Paraíba government deals with the conservation of the PAs it manages, especially its parks. The SUDEMA, its operational arm, struggles with serious limitations such as the absence of qualified personnel, lack of political support, low financial resources, and limited physical facilities and infrastructure (Alegria 2007). We believe that the Paraíba government could take advantage from the possibility of sharing the management with a Civil Society Organization of Public Interest (OSCIP in Portuguese), which is not only permitted by law but also regulated by the Federal Decree $4.340 / 2002$. Shared management is a 'winwin business'. On one side, the Paraíba government may concentrate its limited human and financial resources on regulating the partnership term signed with the OSCIP. On the other side, the OSCIP can easily handle the administrative, bureaucratic and labor challenges involved in Park administration, generating profits, employing local people, and following any government requirement listed in the partnership term. Under this model of management, the park will continue to be public, but their social and conservation goals will be achieved along with the private initiative of public interest.

This is very different from privatizing the park, which is not a solution for the XemXem Park at all. We acknowledge that adopting a private model of management is also beneficial to the nature conservation (Swanson 1997) and that Colombian, Costa Rican, South African and New Zealander systems might be adapted to our reality. Colombia, for instance, has a well-organized network of more than 100 private reserve owners, which, according to the Worldwide Fund for Nature, provides an alternative to the government's insufficient management of 
natural areas, and directly involves citizens as stewards of their country's own natural resources (WFN 1997). However, we pointed out that only privately owned parks will not and should not replace public parks (Langholz and Lassoie 2001), but in both cases it is crucial that reserves develop meaningful links with the surrounding communities, providing employment and promoting environmental awareness and education (Alderman 1994; Langholz 1996).

\section{Distinct perceptions but similar solutions}

As noticed, both groups differ in the way they describe the Park. On the one hand, the Park is defined by staff according to its importance for natural resources conservation and was based on a technical approach, not considering subjectivity or incorporation of local values, indicating that the meanings of the lived-world are constantly obscured by scientific concepts and the adoption of social conventions (Relph 1979). According to Ferreira (2005) public people use wide references to delimit and homogenize a complexity of phenomena (spatial and historical). In turn, residents describe the Park according to not only a visual perception but also based on direct or indirect contact with protected area. The different opportunities highlight the value of the experiences lived daily by the social actors in the construction of their perceptions, and the perceptions related to positive experiences (topophilia) or negative evaluations (topophobia) (Tuan 1974).

Similar to our observations, the knowledge about functions of the Park differ between two groups, not only based on the contact and the experiences lived by both, but mainly due to the absence of SUDEMA in the surrounding communities. However, the similar way in perceiving problems as well as the suggesting of similar solutions to solve them indicate that the two groups share perceptions and perspectives about limitations presented by protected area. This indicates that both life experiences and direct contact with the Park for residents and the technical knowledge by staff may be complementary in the search for efficient solutions.

\section{CONCLUSIONS}

A myriad of problems of social, political, economic and administrative orders are precluding the Xem-Xem Forest State Park to accomplish their socioecological goals. Urban violence, conflicts in forest use and lack of communication with residents stand as barriers to the implementation and effectiveness of conservation actions by SUDEMA. We stress that surrounding residents should be seen as allies for conservation and, as such, should participated in the management of the Park, sharing their needs and expectation with the staff members. Our analyzes revealed how issues of social importance, such as violence and basic infrastructural problems in urban areas, can affect the social representations of nature and their effects on feeling of belongingness, nature appreciation and biodiversity conservation. An interdisciplinary and multi-institutional approach is urgent to implement broad social policies at the local level, with emphasis on the promotion of safety, basic infrastructure and sanitation assistance, offering the best conditions for education and health for residents. The Paraíba government should fortify SUDEMA, hiring fulltime employees and reducing the social distance between people and Park. In summary, we recommend (1) the creation of 
the Park's management council, (2) the development of its management plan, (3) the implementation of public policies surrounding the area to ameliorate conditions for public use and improve biodiversity protection and (4) the continuity of ethnographic researches focusing on the relationship between local communities and the Park.

\section{ACKNOWLEDGMENTS}

We are grateful to the residents of the communities that agree to participate in this research. We also thank the SUDEMA staff for the information provided, the ICMBio (Instituto Chico Mendes de Conservação da Biodiversidade) for partial support to the fieldwork, and Carolina Holanda for producing the map of the study area. BAS thanks the CNPq for research grant.

\section{REFERENCES}

Abílio FJP, Sato M (2012) Educação Ambiental: do currículo da educação Básica às vivências educativas no contexto do semiárido paraibano. João Pessoa: Editora Universitária da UFPB, pp. 492.

Albuquerque UP, Lima Araújo E, El-Deir ACA, de Lima ALA, Souto A, Bezerra BM, Ferraz EMN, Maria Xavier Freire E, Sampaio EV de SB, LasCasas FMG, de Moura GJB, Pereira GA, de Melo JG, Alves Ramos M, Rodal MJN, Schiel N, de Lyra-Neves RM, Alves RRN, de AzevedoJúnior SM, Telino Júnior WR, Severi W (2012) Caatinga Revisited: Ecology and Conservation of an Important Seasonal Dry Forest. The Scientific World Journal 2012:1-18.

Alderman C (1994). The economics and the role of privately owned lands used for nature tourism, education, and conservation. In Munasinghe M, McNeely J, eds. Protected Area Economics and Policy: Linking Conservation and Sustainable Development. Washington (DC): IUCN and World Bank. 273-305p.

Alegria MFDC (2007) Desafios à Gestão de
Unidades de Conservação: uma análise a partir do Conselho Gestor da Ilha do Mel, Paranaguá, PR. M.Sc. dissertation - Instituto de Psicologia, Universidade Federal do Rio de Janeiro - UFRJ, Rio de Janeiro, Brasil, pp. 292.

Alves RG, Pereira JLR, Coimbra LAB, Fontes MAL, Alves LWR (2010) Análise Da Gestão Das Unidades De Conservação Do Sistema Estadual De Áreas Protegidas De Minas Gerais. Espaço e Geografia 13:1-35.

Alves RRN (2012) Relationships between fauna and people and the role of ethnozoology in animal conservation. Ethnobiology and Conservation 1:1-69.

Alves RRN, Nishida AK (2002) A ecdise do caranguejo-uçá, Ucides cordatus L.(Decapoda, Brachyura) na visão dos caranguejeiros. Interciencia 27:110-117.

Alves RRN, Nishida AK, Hernández MIM (2005) Environmental perception of gatherers of the crab "caranguejo-uçá" (Ucides cordatus, Decapoda, Brachyura) affecting their collection attitudes. Journal of ethnobiology and ethnomedicine 1:10.

Alvey AA (2006) Promoting and preserving biodiversity in the urban forest. Urban Forestry and Urban Greening 5:195-201.

Bardin L (1977) Análise de Conteúdo. Rio de Janeiro: Edições 70, pp. 229.

Bawa KS, Seidler R, Raven PH (2004) Reconciling conservation paradigms. Conservation Biology 18:859-860.

Benjaminsen TA, Svarstad H (2010) The death of an elephant: conservation discourses versus practices in Africa. Forum for Development Studies 37:385-408.

Bensusan N (2006) Conservação da biodiversidade em áreas protegidas. Rio de Janeiro: Ed. FGV, pp. 176.

Berkes F, C Johan and Folke C (2016) Rediscovery of Traditional Ecological Knowledge as Adaptive Management. Applications, Ecological 10:1251-1262.

Blaikie P (2006) Is Small Really Beautiful? Community-based Natural Resource Management in Malawi and Botswana. World Development 34:1942-1957.

Borrini-Feyerabend G, Kothari A, Oviedo G (2004) Indigenous and Local Communities and Protected Areas: Towards Equity and 
Enhanced Conservation: Guidance on Policy and Practice for Co-managed Protected Areas and Community Conserved Areas. IUCN, Gland, Switzerland and Cambridge, UK, pp. 111.

Brasil. Decreto $N^{\circ}$ 4340/2002. Regulamenta artigos da Lei no 9.985 , de 18 de julho de 2000, que dispõe sobre o Sistema Nacional de Unidades de Conservação da Natureza - SNUC, e dá outras providências. Ministério do Meio Ambiente, Brasília. [http://www.mma.gov.br/port/conama/legiabre.cf m?codlegi=374] Acessed on 16 june 2016.

Brasil. Lei $n^{\circ}$ 9.985, de 18 de Julho de 2000. Regulamenta o artigo 225, $\S 1^{\circ}$, incisos I, II, III e VII da Constituição Federal, institui o Sistema Nacional de Unidades de Conservação da Natureza e dá outras providências. Ministério do Meio Ambiente,

Brasília. [http://www.planalto.gov.br/ccivil_03/leis/L9985.ht m] Acessed on june 2016.

Brechin SR, Wilshusen PR, Fortwangler CL, West PC (2002) Beyond the Square Wheel: Toward a More Comprehensive Understanding of Biodiversity Conservation as Social and Political Process. Society \& Natural Resources 15:41-64.

Brito MCW (2000) Unidades de conservação: intenções e resultados. São Paulo: Annablume; FAPESP, pp. 230.

Brun F, Link D, Brun E (2007) O emprego da arborização na manutenção da biodiversidade de fauna em áreas urbanas. Revista Brasileira de Arborização Urbana. 2:117-127

Campbell LM (2002) Conservation Narratives in Costa Rica: Conflict and Co-existence. Development and Change 33:29-56.

Cardoso SLC, Sobrinho MV, Vasconcellos AM de A (2015) Gestão ambiental de parques urbanos: o caso do Parque Ecológico do Município de Belém Gunnar Vingren. Revista Brasileira de Gestão Urbana7:74-90.

Carneiro G (2011) The Luiz Saldanha Marine Park: An overview of conflicting perceptions. Conservation and Society 9:325.

Ceríaco LM (2012) Human attitudes towards herpetofauna: The influence of folklore and negative values on the conservation of amphibians and reptiles in Portugal. Journal of Ethnobiology and Ethnomedicine 8 (8): 1-12.

Chelimsky E (1991) On the social science contribution to governmental decisionmaking. Science (New York, N.Y.) 254:226-31.

Chiesura A (2004) The role of urban parks for the sustainable city. Landscape and Urban Planning 68:129-138.

Clarke KR and Gorley R (2001). PRIMER V5: User Manual/ Tutorial. PRIMER-E. Plymouth, UK, pp. 91.

Conforti VA, Azevedo FC (2003) Local perceptions of jaguars ( Panthera onca) and pumas ( Puma concolor) in the Iguaçu National Park area, south Brazil. Biological Conservation 111:215-221.

Cunningham AB (2001) Applied Ethnobotany: people and plants conservation manuals. Routledge. WWF, UNESCO and Royal Botanic Gardens Kew, pp. 321.

Davidoff LF (1993) Introdução à psicologia. São Paulo: McGraw - Hill do Brasil, pp. 237.

Dearborn DC, Kark S (2010) Motivaciones para conservar la biodiversidad urbana. Conservation Biology 24:432-440.

Del Rio V (1991) Desenho Urbano e Revitalização na Área Portuária do Rio de Janeiro A Contribuição do Estudo da Percepção Ambiental. PhD thesis. FAU. Universidade de São Paulo, pp. 548.

Donaldson T, Preston LEEE (1995) The Stakeholder Theory of the Corporation: Concepts, Evidence, and Implications. The Academy of Management Review. 20(1):65-91.

Dourojeanni MJ (2002) Vontade política para estabelecer e manejar parques. In: Terborgh, J.; Van Schaik, C.; Davenport, L.; Rao, M.Tornando os parques eficientes:estratégias para a conservação da natureza nos trópicos. Curitiba: Universidade Federal do Paraná; Fundação O Boticário de Proteção à Natureza, pp. 347-362.

Ferreira CP (2005) Percepção Ambiental na Estação Ecológica de Juréia-Itatins. M.Sc Dissertation. Programa de Pós-Graduação em Ciência Ambiental. Universidade Federal de São Paulo, pp 161.

Fisher BS and Nasar JL (1992) Fear of crime in relation to three exterior site features: Prospect, refuge, and escape. Environment and Behavior, 24,35-65.

Goodman LA (1961) Snowball Sampling. The Annals of Mathematical Statistics 32:148-170. 
Groff E, McCord ES (2012) The role of neighborhood parks as crime generators. Security Journal 25:1-24.

Hunter MR and Hunter MD (2008) Designing for conservation of insects in the built environment. Insect Conservation and Diversity 1:189-196.

Hurrell JA, Albuquerque UP (2012) Is Ethnobotany an Ecological Science? Steps towards a complex Ethnobotany. Ethnobiology and Conservation 1:1-16.

Jeffery CR (1971) Crime Prevention through Environmental Design. Beverly Hills, CA: Sage Publications, pp 351.

Kaplan R (1985) The analysis of perception via preference: A strategy for studying how the environment is experienced. Landscape Planning 12:161-176.

Kärre E (2007) Environmental Perceptions in an Urban Environment. Human Ecology Division, Lund University, pp 78.

Kinker S (2002) Ecoturismo e Conservação da Natureza em Parques Nacionais. 1 ed. Papirus, Campinas, SP, Brazil, pp 224.

Knight AT, Cowling RM (2006) Into the thick of it: bridging the research-implementation gap in the thicket biome through the Thicket Forum. South African journal of science 102:406-408.

Kuo FE, Bacaicoa M, Sullivan WC (1998) Transforming Inner-City Landscapes: Trees, Sense of Safety, and Preference. Environment and Behavior 30(1): 28-59.

Kuo FE, Sullivan WC (2001) Environment and crime in the inner city: Does vegetation reduce crime? Environment and Behavior 33:343-367.

Langholz J (1996) Economics, Objectives, and Success of Private Nature Reserves in SubSaharan Africa and Latin America. Society for Conservation Biology 10:271-280.

Langholz JA, Lassoie JP (2001) Perils and Promise of Privately Owned Protected Areas. BioScience 51:1079-1085.

Leão RM (2000) A floresta e o homem. Editora da Universidade de São Paulo: Instituto de Pesquisas e Estudos Florestais, pp 444.

Lourenço JDS, Silvestre LC, Farias RP, Barros SCA, Xavier SRS. (2009) Composição Florística De Pteridófitas em Dois
Remanescentes De Floresta Atlântica Nordestina - Mata De Goiamunduba E Mata Do Xemxem. Anais do IX Congresso de Ecologia do Brasil. 1-3.

Manfredo M, Teel T, Bright AD (2004) Application of the concepts of values and attitudes in human dimensions of natural resources research. In: Manfredo $M$, Vaske $J$, Bruyere B, Field D, Brown P. Society and Natural Resources: A Summary of Knowledge. Modern Litho, Jefferson, MO, USA, pp. 271-282.

Matteson KC, Grace JB, Minor ES (2013) Direct and indirect effects of land use on floral resources and flower-visiting insects across an urban landscape. Oikos 122:682-694.

Medeiros PM (2013) Why is change feared? Exotic species in traditional pharmacopoeias. Ethnobiology and Conservation 2:1-5.

McLaughlin CM (2011) People Living in Protected Areas: a Comparative Study of the Social Impacts of Conservation in Latin America's Mamirauá Sustainable Development Reserve and Ría Celestún Biosphere Reserve. Master of Arts Thesis. International Affairs and Natural Resources and Sustainable Development American University United Nations' University for Peace, pp71.

MMA (2007) Áreas Prioritárias para a Conservação, Uso Sustentável e Repartição de Benefícios da Biodiversidade Brasileira: Atualização - Portaria MMA $n^{\circ} 9$, de 23 de janeiro de 2007. Série Biodiversidade 31. pp. 301.

Nelson F, Agrawal a (2008) Patronage or Participation? Community-based Natural Resource Management Reform in SubSaharan Africa. Development \& Change 39:557-585.

Neves J (1996) Pesquisa qualitativa: características, usos e possibilidades. Caderno de pesquisas em administração São Paulo 1:1-5.

Newman O (1972) Defensible Space: Crime Prevention Through Environmental Design. Macmillian, New York, USA.

Pacheco É and Silva HP (2006) Compromissos Epistemológicos Do Conceito De Percepção Ambiental. [http://www.ivtrj.net/sapis/2006/pdf/EserPacheco.pdf] Acessed on 20 August 2016.

Panquestor EK, Riguetti NK (2008) Percepção 
ambiental, descaso e conservação: uso da geoinformação no estudo de áreas verdes públicas em Carangola - MG. IV Encontro Nacional da Anppas [http://www.anppas.org.br/encontro4/cd/ARQUIV OS/GT8-858-589 20080514164844.pdf] Acessed on 20 August 2016.

Peixoto S, Camphora AL, Ambiental C, Pósgraduação C De (2010) Reflexões Sobre a Gestão de Áreas Protegidas em Cenários de Violência Urbana no Contexto do Parque Nacional da Tijuca, Rio de Janeiro. [http://www.anppas.org.br/encontro4/cd/ARQUIV OS/GT2-926-712-20080518092725.pdf] Acessed on 23 August 2016.

Philippi Jr A, Roméro MA, Bruna GC (2004) Curso de Gestão Ambiental. 2 ed Manole, Barueri, SP, Brazil, pp. 1250.

Piaget J (1969). The mechanics of Perception. New York: Basic Books. pp. 361.

Pope C, Mays N (1995) Reaching the parts other methods cannot reach: an introduction to qualitative methods in health and health services research. BMJ (Clinical research ed.) 311:42-45.

Premauer JM, Berkes F (2015) A Pluralistic Approach to Protected Area Governance: Indigenous Peoples and Makuira National Park, Colombia. Ethnobiology and Conservation 4:1-16

Redford KH, Fearn E (2007) Protected Areas and human displacement: a conservation perspective. Working Paper. WCS Institute and Wildlife Conservation Societ, pp. 152.

Relph E (1979) As bases fenomenológicas da Geografia. In: Geografia. São Paulo, 7(4):1-25.

Rocha M, Cavalcanti PDM (2006) Aspectos da comercialização ilegal de aves nas feiras livres de Campina Grande, Paraíba , Brasil. Revista de Biologia 6:204-221.

Rodrigues ML, Malheiros Tadeu Fabricio, Fernandes V, Darós TD (2012) A Percepção Ambiental Como Instrumento de Apoio na Gestão e na Formulação de Políticas Environmental Awareness as a Support Tool in the Management and Formulation of Environmental Public. Saúde e Sociedade 21:96-110.

Rodriguez-Carreras $\mathrm{R}$, Úbeda $\mathrm{X}$, Outeiro $\mathrm{L}$, Asperó $F$ (2014) Perceptions of social and environmental changes in a Mediterranean forest during the last $\mathbf{1 0 0}$ years: The Gavarres Massif. Journal of Environmental Management 138:75-86.

Sá TV (2000) Segurança e o seu Sentimento na Cidade. Sociedade portuguesa: passados recentes, futuros próximos: actas do IV congresso português de sociologia. [http://www.aps.pt/cms/docs_prv/docs/DPR462dc 462900dd_1.PDF] Acessed on 15 june 2016.

Sachs I, Lopes C, Dowbor L (2010) Crises e oportunidades em tempos de mudança. Economia Global e Gestão. 15(1): 133-154.

Sammarco YM (2005) Percepções sócioambientais em unidades de conservação: 0 Jardim de Lillith? M.Sc dissertation. Universidade Federal de Santa Catarina. Programa de Pós-Graduação em Engenharia Ambiental. Florianópolis, pp. 211.

Savard JPL, Clergeau P, Mennechez G (2000) Biodiversity concepts and urban ecosystems. Landscape and Urban Planning 48:131-142.

Silveira ADM, Yoshinaga CE, Borba $P$ da RF (2005) Crítica À Teoria Dos Stakeholders Como Função-Objetivo Corporativa. Caderno de Pesquisas em Administração 12:33-42.

Swanson T (1997) Global Action for Biodiversity: An International Framework for Implementing the Convention on Biological Diversity. London: Earthscan, pp. 191.

Talbot J, Kaplan R (1984) Needs and Fears: the Response To Trees and Nature in the Inner City. Journal of Arboriculture 10:222-228.

Taylor RB, Harrell A V. (1996) Physical Environment and Crime. U.S. Research Report. National Institute of Justice, pp. 39.

Trakolis D (2001) Local people's perceptions of planning and management issues in Prespes Lakes National Park, Greece. Journal of environmental management 61:227-241.

Ulrich RS (1984) View through a window may influence recovery from surgery. Science (New York, N.Y.) 224:420-421.

WFN - Worldwide Fund for Nature. (1997). The Network of Private Nature Reserves: Strengthening Private Efforts in Conservation and Management of Natural Lands and Resources - Project Profile. Washington (DC):WFN, pp 4.

Whyte A. (1977) Guidelines for field studies in Environmental Perception. MAB Technical 
Notes 5, UNESCO, Paris, France, pp.117.

Yi-fu T (1974) Topofilia. Um estudo da Percepçao, Atitudes e Valores do Meio Ambiente. Eduel. 1 ed, pp. 288.

Zabel CJ, Roberts LM, Mulder BS, Stauffer HB, Dunk JR, Wolcott K, Solis D, Gertsch M, Woodbridge B, Wright A, Goldsmith G, Keckler C (2002) A collaborative approach in adaptive management at a large landscape scale. Predicting species occurrence: issues of accuracy and scale, 241-253.

Received: 26 July 2016

Accepted: 01 February 2017

Published: 02 April 2017 